\title{
Marinușa Constantin, Creativitatea lexicală în limba româna veche, Prefaţă de Petre Gheorghe Bârlea, Editura Muzeul Literaturii Române, Colecția Aula Magna, București, 2017, 319 p.
}

\author{
Cosmin Căprioară ${ }^{\star}$ \\ Facultatea de Litere, Universitatea „Ovidius” din Constanța, Aleea Universității 1, 900472 Constanța, România
}

La Editura „Muzeul Literaturii Române” din București, în colecția Aula Magna, inițiată de criticul și istoricul literar Lucian Chișu și destinată tinerilor cercetători din domeniul filologiei, a apărut cartea Creativitatea lexicală în limba româna veche, o valoroasă contribuție de lexicologie diacronică, semnată de Marinuşa Constantin, membră a corpului didactic al Universității „Valahia” din Tîrgoviște și a Departamentului de Limbă, Cultură şi Civilizație Română din cadrul Universităţii Politehnice din București.

Bazată pe cercetarea doctorală a autoarei, cartea se bucură de o prefață scrisă de profesorul Petre Gheorghe Bârlea, care a fost și coordonatorul științific al acesteia. Avînd în centrul său analiza unor aspecte ale derivării prefixale din etapa veche a limbii române literare, realizată cu metode şi instrumente lingvistice moderne, importanța lucrării ni se revelează din mai multe perspective.

În primul rînd, studiul se focalizează asupra unui aspect al morfologiei derivaționale, delocuţiunea (sau derivare delocutivă, cum o numește Florica Dimitrescu, ori derivare postlocuţională, după Theodor Hristea), ramură a derivării prefixale. Aceasta este privită din perspectiva construcțională, bazată pe modelul asociativ-stratificat (propus de lingvista franceză Danielle Corbin, în Morphologie dérivationnelle et structuration du lexique, vol. I-II, Tübingen, 1987) și aplicată materialului lingvistic excerptat din texte diverse, religioase și laice, aparținînd primelor două etape de evoluție ale limbii române literare (15321640, respectiv 1640-1780), acceptate ca atare de majoritatea specialiștilor.

În al doilea rînd, avem de a face cu o cercetare diacronică, realizată pe un material lexical deosebit de bogat, excerptat din dicționarele curente ale limbii române și din cuprinsul unui mare număr de texte, originale și traduceri din perioada amintită, și privește o fază din evoluția limbii care are încă nevoie de cercetări de detaliu.

$\mathrm{Nu}$ în ultimul rînd, trebuie subliniată complexitatea temei tratate, în condițiile în care „cercetarea constituie, în esență, o analiză a delocuțiunii din perspectivă etimologică, logico-semantică, stilistico-funcțională, accentul căzînd asupra aspectului logico-semantic" (Introducere, p. 19). Tot în acest sens, merită subliniat faptul că se urmărește inclusiv „confirmarea așa-numitei «competențe derivaționale de tip generativ»" (loc. cit.), atît de necesară în procesul creativității lexicale, și se examinează „constituirea unui sistem al mecanismului delocuţiunii organizat în niveluri ierarhice” (ibid., p. 20), care are la bază prefixele vechi $a-, d e-$ și în-.

O temă complexă presupune și o metodologie de abordare complexă. Autoarea apelează la o gamă cuprinzătoare de metode, procedee și instrumente de lucru. Dintre metodele de cercetare, care, în opinia semnatarului prefeței, „reprezintă, în mod categoric, (...) cel mai semnificativ" element de plus-valoare (p. 6), locul principal îl ocupă metoda descriptivă, asociată cu perspectiva construcțională despre care am vorbit. Acestea au ca fundal principiile morfologic și semantic, presupuse de modelul de cercetare ales, dar şi pe cel al analogiei, atît de prezent mai ales în remodelarea paradigmelor verbale. $\mathrm{Li}$ se adaugă principiul fonetic, necesar pentru explicarea unor modificări de formă a derivatului în raport cu baza (vezi, în special, cazul lui inflori). Cercetarea se realizează în diacronie, ceea ce implică utilizarea unor aspecte ale metodei comparative ce țin mai ales de cronologie și de frecvență. Autoarea apelează, de asemenea, la analiza funcțională, care permite reducerea diferitelor variante ale unui derivat la o invariantă, și, mai puțin, la onomasiologie, obiectivul principal nefiind clasificarea exhaustivă a noțiunilor.

\footnotetext{
*Adresă de corespondență: ct.caprioara@yahoo.fr.
} 
Grilele de analiză sînt adaptate textelor religioase și laice pe baza cărora se realizează cercetarea.

Privită în ansamblu, cartea reprezintă o construcție armonioasă, adecvată temei și urmărind logic etapele de cercetare și de tratare a acesteia. Structurarea în cinci capitole, precedate de o necesară Introducere și succedate de Concluziile generale și de Bibliografie, răspunde nu doar la necesitățile unei lucrări de gen, dar și la cele obiective, cerute de complexitatea problemelor tratat. Lucrarea se încheie $\mathrm{cu}$ foarte utilele Indice de afixe și Indice de cuvinte, organizate pe limbi de proveniență, care îi subliniază destinația științifică și facilitează accesul cititorului la numărul bogat de forme analizate, care, după cum observă profesorul P.Gh. Bârlea, „constituie deja o prețioasă sursă de informare pentru viitoarele studii de vocabular, gramatică istorică, dialectologie, contrastivitate, stilistică, teoria mentalităţilor etc." (Prefaţă, p. 9).

În Introducere, autoarea argumentează alegerea temei, prezintă structura cărții, stadiul cercetărilor, metodele de lucru, selecția termenilor și face cuvenitele precizări terminologice. În ceea ce privește stadiul cercetărilor, se remarcă valoroasele contribuții privitoare la derivarea cu prefixe în general, existente atît la nivel național, cît și la nivel internațional (a se vedea, în afară de contribuțiile lui Danielle Corbin, lucrarea lui Mark Aronoff din 1976, Word Formation in Generative Grammar, Cambridge, clasicul de acum tratat Formarea cuvintelor in limba română (FCLR) sau volumul din 2007, coordonat de Magdalena Popescu-Marin, despre formarea cuvintelor în secolele al XVI-lea și al XVII-lea). În aceeași ordine de idei, se observă lipsa unei cercetări românești din perspectiva modelului corbinian ori a unei analize a procesului metaforic, de tipul celei propuse pentru verbele derivate cu prefixele $\hat{\imath} n-s, i a-$.

Capitolul I, intitulat Derivarea din perspectivă construcțională, prezintă cadrul teoretic de analiză a fenomenului derivării delocutive. Mai precis, sînt aduse în discuție cîteva modalităţi de interpretare, în maniera lui D. Corbin, a acestui proces, prezent încă din etapele vechi ale limbii române literare, prin prisma competenței derivaționale. Aceasta este legată de raportul dintre formă și sens din cadrul cuvintului construit (unde sensul său compozițional este condiționat de raportul dintre predictibilitatea semnificației lexicale a acestuia și structura sa morfologică). Autoarea insistă asupra regulilor de „construire a cuvintelor (RCC), care acționează sistematic atît la nivelul bazei, cît și al cuvîntului construit, presupunînd existența unor operații de ordin categorial, semantico-sintactic și morfologic" (p. 69), precum și asupra regulilor de construire semantică a cuvintelor (RCSC, în lucrare).

În capitolul al II-lea, $\boldsymbol{A -}{ }_{1}, \boldsymbol{d e -}{ }_{3}, \hat{i n}_{-}{ }_{1}$ cu valoare de preverb, prepoziție, prefix, se discută și se precizează valorile uzuale pe care le dobîndesc aceste formative, avîndu-se în vedere „problematica impusă de omonimia gramaticală a cuvintelor $a$, de și în din perspectiva funcțiilor lexico-gramaticale pe care le îndeplinesc cele trei elemente moștenite din limba latină populară, și anume, prepoziție, preverb și prefix, restrîngînd sfera de analiză la perspectiva relației preverb-prefix” (p. 21-22). Sînt evidenţiate "câteva aspecte legate de teoretizarea conceptului de 'preverb', respectiv, de clasele și funcțiile semantice exercitate de această particulă, în plan diacronic și sincronic" (p. 22).

În cel de-al treilea capitol, fundamental, Aspecte ale delocuțiunii în limba română literară veche, care constituie centrul de greutate al cărții, se face trecerea către cercetarea aplicată pe corpusul stabilit de autoare. Aceasta alcătuiește un inventar al derivatelor postlocuționale cu prefixele $a-, d e-s, i$ in-, din principalele texte vechi din secolele al XVI-lea al XVIII-lea. Inventarul ține cont de raporturile categoriale specializate existente între temele lexicogramaticale și prefixele amintite, de tiparele de derivare delocutivă și de gradul de productivitate al acestora.

Autoarea observă mecanismele care asigură continuitatea termenilor atestați în prima perioadă și construirea altora, fapt care impune o dezvoltare a tuturor compartimentelor limbii, mai ales a lexicologiei și a morfologiei: „Fenomenul delocuțiunii, des întâlnit în textele din secolele al XVI-lea al XVIII-lea, oferă informații privind conturarea unor tipare logico-semantice şi morfologice care acționează sistematic și ierarhic în cadrul lexicului." (p. 102).

Capitolul al IV-lea, cu titlul Tipare logicosemantice ale derivatelor $c u a-{ }_{1}$ și in- $-_{1}$, reprezintă o abordare din perspectivă logico-semantică și sintactică a derivării delocutive. De aceea, autoarea urmărește valorile conceptuale exprimate de afixele $a-, d e-s, i$ în-, în raport cu temele cărora li se ataşează, și face o departajare a subtipurilor verbelor eventive, 
în funcție de semele [dinamic] și [schimbare].

Al cincilea capitol, Verbe derivate $c u$ in- $c u$ evoluție metaforică, combină teoria asupra figurilor limbajului propuse de Grupul $\mu$ în Retorica generală $\mathrm{cu}$ perspectivele teoriei cognitive asupra metaforei, lansată de G. Lakoff și M. Johnson, în Metaphors We Live By, delimitîndu-se un microcîmp semantic al metaforelor create prin intermediul derivării cu prefixul in-.

În urma acestui demers complex, Marinuşa Constantin ajunge la cîteva concluzii generale deosebit de importante, în contextul lingvisticii diacronice, în general, și al studierii limbii române literare vechi, în special.

Se remarcă, astfel: productivitatea derivării delocutive în textele românești vechi, unde este preferat prefixul $\hat{\imath}$-, prezent într-un număr mare de verbe denominative, de adjective și substantive parasintetice (554 de ocurențe); anumite aspecte ale dinamicii limbii în perioada veche, în ambele categorii de texte-religioase și laice-fiind utilizate în paralel forme prefixate și neprefixate de la aceeași bază; procesul de evoluție și de rafinare a limbii noastre literare în faza sa veche, de la concurența formelor prefixate cu cele neprefixate pînă la folosirea unor derivate cu $\imath_{n}$ - și $a-$ din rațiuni stilistice şi prozodice, la Dosoftei și Cantemir; exprimarea valorilor logico-semantice ale derivatelor $\mathrm{cu} \hat{\imath} \mathrm{n}$-, care se face în funcție de părțile de vorbire care constituie baza; disocierea dificilă dintre valoarea eventivă și cauzativă a unor verbe (mai ales reflexive eventive), în textele românești vechi; analiza generativă la care pot fi supuse verbele derivate cu în-, observîndu-se astfel aplicarea unor reguli de transformare prelexicală, în care cel mai adesea apare verbul primar a deveni; polisemia substantivelor şi a adjectivelor derivate $\mathrm{cu}$ in-; predominanța metaforelor ontologice etc.

Bibliografia, împărțită pe categorii de surse, este foarte bogată, adecvată temei și actuală, iar autoarea dovedește permanent pe parcursul cărții că știe să o folosească inteligent, tocmai datorită selecţiei potrivite făcute și însuşirii critice a conceptelor și teoriilor. De altfel, bogăţia documentării şi buna apropriere a teoriilor şi modelelor se reflectă și în exprimarea textuală clară, curgătoare şi precisă.

În final, merită subliniat faptul că lucrarea nu numai că identifică, descrie și analizează, în mod ştiințific și profesionist, fapte de limbă veche prin prisma teoriilor moderne, constituind, prin aceasta, un reper în studiul diacronic al limbii noastre, ci și că deschide noi direcții de cercetare, noi oportunități de studiu și de reflecție, în primul rînd pentru lexicologi și lexicografi, care sînt nevoiți, în consecință, să revadă sau să completeze etimologia anumitor termeni. Chiar autoarea își propune să urmărească procesul derivării delocutive şi în perioadele limbii române moderne şi contemporane. $\mathrm{O}$ astfel de cercetare ar fi posibilă și la nivel comparativ romanic. În plus, cartea constituie un valoros și util instrument de lucru pentru studenții și profesorii din domeniul filologic, dar și pentru publicul larg, interesat de devenirea limbii române. 